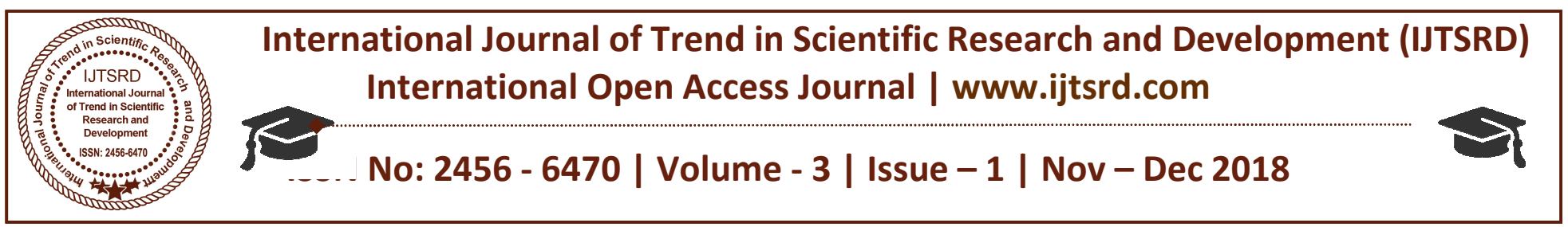

\title{
Influence of Digital Marketing on Consumer Purchase Behavior
}

\author{
Keerthi Krishna M \\ Assistant Professor, Department of Commerce, \\ N S S College Pandalam, Kerala, India
}

\begin{abstract}
Digital marketing is a marketing method to promote products in online .Digital Marketing industry in India is spread to almost all the business sectors. The power of digital marketing allows geophysical barriers to disappear making all consumers and businesses on earth potential customers and suppliers. It is known for its ability to allow business to communicate and form a transaction anywhere and anytime. Apart from that, it too lays down the impact on the mind of the customer so as to purchase the product. The purpose of study is to recoganize the effectiveness and the impact of digital marketing in the buying behavior of consumers. For the data collection, Primary data is used. A structured questionnaire is used to collect primary data and the sample size is 50 respondents. The findings of the study reveals that the customer is aware of the digital media and more likely uses the digital channel for shopping goods. This study conducted in chengannur taluk in Pathanamthitta District.
\end{abstract}

KEY WORDS: Digital Marketing, Customer Buying Behaviour, Consumer awareness, Chenganur Taluk

\section{INTRODUCTION}

Today's time of Internet has opened the gateway of tremendous digital marketing opportunities for businesses. By utilizing different channels of digital marketing, businesses cannot just share their product and services online; additionally they can gain clients for their business, entice them and can convert them to boost their ROI .The world is super-connected nowadays and all things considered, marketing and advertising are no more the same as they once were. This is particularly valid because of the ascent of online networking, which has changed how organizations speak with potential and existing customers.

Digital market helps corporate to reach target customer via different channels like E- marketing, Ecommerce, social media, websites, interactive marketing. Marketer can conducted online survey so as to get the required information from customer and analyse the response and correspondingly take action based on response of customers to meet their needs.

Digital Marketing is new form of marketing and opportunities for enterprise to communicate the potential customers. Digital marketing campaigns are becoming more prevalent as well as efficient, as digital platforms are increasingly incorporated into marketing plans and everyday life, and as people use digital devices instead of going to physical shops.

With the emergence of digital marketing, it is not an easy task anymore to woo the consumers.. To match the consumer-set standards, every brand has to make sure to be on their toes and everyone has maintained its presence on the social media platforms. Era has changed and so the mindset of the consumers. Consumers are now welcoming new products with fresh and good quality features with applause.

With so many options available in the market, it becomes difficult for the consumers to become loyal and switching becomes easy.It is the consumers that decide which social media platform the brand must use to expand its business. If the mass consumers are on Facebook, Snapchat, Twitter, Instagram, LinkedIn etc., it becomes mandatory for the brands to have their presence on these platforms if they want to be close to their prospects and a step ahead of their competitors, by interacting with their consumers and creating a buzz of their brand among them. 


\section{Objectives of the Study}

$>$ To recognize the effectiveness of digital marketing among consumers.

$>$ To study the impact of digital marketing on consumer buying behavior.

\section{Methodology Applied}

Primary Data : The research is done through observation and collection of data through structured questionnaires from 50 respondents.

Secondary Data : Secondary data is collected from newspapers, journals, books and magazines to develop the theory.

Sample Size : For this study, the sample size 50 was taken for analysis.

\section{How does Internet marketing benefit consumers}

While increased visibility and access is definitely good for your business, Internet marketing also benefits your customers. Internet marketing is a way to lead consumers honestly toward your product or service based on their criteria. Presenting them with the right, useful information at the correct time lets them make the choice to engage you, instead of you going after them.

1. Consumers want relevant, engaging, and newsworthy content on demand. This means they expect to receive news about your industry as soon as it occurs, statistics about your industry, and other relevant information as it emerges. Internet marketing ensures consumers can find what they need to stay up-to-date. .

2. The Internet offers consumers a greater variety and choice than they've ever had before. In this way, Internet marketing is a huge benefit to consumers on a global scale.

3. Consumers can find information about your business at any time of the day. This effectively gives them unlimited access to the brand, allowing to engage potential consumers ie Digital marketing provides $24 / 7$ access

4. Internet marketing gives you a chance to reduce paper as more marketing campaigns shift to digital, Marketers can work from anywhere, cutting down on fossil fuel use, Online shoppers don't need to drive to stores to find what they want.

\section{ANALYSIS AND INTERPRETATION}

\begin{tabular}{|c|c|c|c|}
\hline Question & Category & $\begin{array}{l}\text { No of } \\
\text { respondents }\end{array}$ & $\begin{array}{l}\text { \% of } \\
\text { respondents }\end{array}$ \\
\hline \multirow[t]{3}{*}{ Gender } & Male & 30 & 60 \\
\hline & Female & 20 & 40 \\
\hline & Total & 50 & 100 \\
\hline \multirow[t]{5}{*}{ Age } & Below20 & $10 \quad 0=$ & 20 \\
\hline & $21-30$ & 15 & 30 \\
\hline & $31-40$ & 14 & 28 \\
\hline & 41 above & 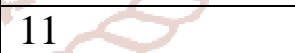 & 22 \\
\hline & Total & 50 & 100 \\
\hline \multirow[t]{4}{*}{ Qualification } & Under graduate & 12 & 24 \\
\hline & Graduate & 20 & 40 \\
\hline & Post graduate & 18 & 36 \\
\hline & Total & 50 & 100 \\
\hline \multirow[t]{6}{*}{ Occupation } & Students & 8 & 16 \\
\hline & Housewife & 11 & 22 \\
\hline & Govt employees & 9 & 18 \\
\hline & Business people & 10 & 20 \\
\hline & Private employees & 12 & 24 \\
\hline & Total & 50 & 100 \\
\hline \multirow[t]{4}{*}{ Monthly income } & Below 10000 & 8 & 16 \\
\hline & $10001-20000$ & 12 & 24 \\
\hline & $20001-30000$ & 10 & 20 \\
\hline & $30001-40000$ & 11 & 22 \\
\hline
\end{tabular}


International Journal of Trend in Scientific Research and Development (IJTSRD) ISSN: 2456-6470

\begin{tabular}{|c|c|c|c|}
\hline & Above 40000 & 9 & 18 \\
\hline & Total & 50 & 100 \\
\hline $\begin{array}{l}\text { Awareness of digital } \\
\text { shopping }\end{array}$ & $\begin{array}{l}\text { Having knowledge about } \\
\text { digital marketing }\end{array}$ & 42 & 84 \\
\hline & $\begin{array}{l}\text { Not Having knowledge about } \\
\text { digital marketing }\end{array}$ & 8 & 16 \\
\hline & Total & 50 & 100 \\
\hline Which of the digital & Emails & 6 & 14 \\
\hline channel do you aware & Social media & 10 & 24 \\
\hline & Website & 13 & 31 \\
\hline & Multimedia ads & 8 & 19 \\
\hline & Others & 5 & 12 \\
\hline & Total & 42 & 100 \\
\hline Which digital channel & Emails & 4 & 10 \\
\hline influence you more to & Social media & 14 & 33 \\
\hline & Website & 15 & 36 \\
\hline & Multimedia ads Cle & 4 & 10 \\
\hline & Others & 5 & 11 \\
\hline & Total & 420 & 100 \\
\hline What kind of product & Convenience goods & $10 \circlearrowleft$ & 24 \\
\hline you prefer to bu & Speciality goods & 70 & 16 \\
\hline & Shopping goods & $25 \quad 0$ & 60 \\
\hline & Total & 42102 & 100 \\
\hline Reasons for chc & Low price & 8 & 19 \\
\hline digital shopping & Variety of products & $10 \mathrm{C}$ & 24 \\
\hline & Various payment mode & 0 & 21 \\
\hline & Easy buying procedure all & 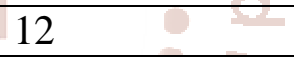 & 29 \\
\hline & Others & 0 & 7 \\
\hline & Total & 420 & 100 \\
\hline Frequency & Once in a year & 5 & 12 \\
\hline purchasing & $2-5$ times & 7 & 17 \\
\hline & $6-10$ & 22 & 52 \\
\hline & 11 and above & $8+0$ & 19 \\
\hline & Total & $2=$ & 100 \\
\hline Problems that faced & Security issues & $11<$ & 26 \\
\hline when you use digital & Payment failures & 6 & 15 \\
\hline channels for shopping & Authenticity & 9 & 21 \\
\hline & Additional charges & 7 & 17 \\
\hline & Quality issues & 9 & 21 \\
\hline & Total & 42 & 100 \\
\hline
\end{tabular}

$>$ Ratio of male customers is very high in online shopping that is $60 \%$

$>$ Awareness about digital shopping is $84 \%$ among the respondents

$>$ Income of respondents mainly falls in the range of Rs.10001-20000ie 24\%

$>$ Private employees are purchasing more than others through online shopping that is $24 \%$.
Most numbers of respondents that is $29 \%$ feels that online shopping have simple buying procedures.

$52 \%$ of the respondents purchase the products 6 to 10 times annually.

Majority of the respondents were influenced to buy more products through websites

$60 \%$ of the respondents prefer to buy shopping goods through digital channels 
$>$ The major problem faced by the respondents were the security issues ie $26 \%$

$>$ Overall the respondents are satisfied through purchasing digital marketing.

\section{Conclusion}

Digital marketing is about utilizing digital technology to achieve marketing objectives. There is no essential need for digital marketing to always be separate from the marketing department as a whole, as the objectives of both are the same. However, for now, it remains a useful term because digital marketing requires a certain skill set to utilize the digital technology effectively.

At the present time, still for tiny business proprietor at hand have an extremely inexpensive and competent method by using digital marketing to market their products or services in the society. It has no restrictions. Company can utilize any devices such as tablets, smart phones, TV, laptops, media, social media, e-mail and lot other to support company and its products and services. Digital marketing may achieve more if it considers high priority.

\section{References}

1. Basheer. A. M. Al-alak. (2010). "Mobile marketing: examining the impact of trust, privacy concern and consumers' attitudes on intention to purchase". International journal of business management, 5.

2. Chaffey D, E-business \& e-Commerce Management- Strategy, Implementation and Practice Pearson Education, Paris, 2011, 72-79

3. Gangeshwer DK, E-Commerce or Internet Marketing: A Business Review from Indian Context", International Journal of - and e- Service, Science and Technology.

4. Vishal Midha, Article- Impact of Consumer Empowerment on Online Trust: An Examination across Genders, Elsevier International Journal, 12(3), 2012, 198-205.

5. International Journal of Marketing Studies, 3(1), 2011, 128-139. 